\title{
DEVELOPMENT AND STANDARDISATION OF HIGH FREQUENCY WORD IDENTIFICATION TEST FOR ADULTS IN GUJARATI LANGUAGE
}

Contributions: A Study design/planning B Data collection/entry C Data analysis/statistics D Data interpretation E Preparation of manuscrip F Literature analysis/search $\mathrm{G}$ Funds collection

\section{Gunjan Mehta ${ }^{A B C D E F}$, Anuj Kumar Neupane ${ }^{A D E F}$}

Department of Audiology and Speech Therapy, C.U. Shah Medical College and Hospital, Surendranagar, Gujarat, India

Corresponding author: Gunjan Mehta, Department of Audiology and Speech Therapy, C.U. Shah Medical College and Hospital, Surendranagar 363001, Gujarat, India.

Email: gunjanmehta06@gmail.com; Phone: +91 9664952636

\begin{abstract}
Background: Evaluation of an individual's hearing involves administering a test battery, and these assessments collectively complement each other in defining the degree, type, and configuration of hearing loss. Among the acoustic stimuli used in such tests, speech signals are the most complex and possess significant redundancy. Therefore the use of conventional word lists during routine audiological evaluation may, through redundant information, lead to overestimation of the performance of individuals with high-frequency sloping hearing loss. The Gujarati language, with 56 million native speakers in India, currently has only a conventional speech identification test. The present study aimed at developing and standardizing high-frequency word lists in Gujarati.

Material and methods: The study was conducted in three phases. Phase I: development of high-frequency word lists in Gujarati. Phase II: establishment of norms for the developed word lists on 180 normal hearing individuals belonging to different geographic regions of Gujarat. Phase III: Checking the applicability on 25 individuals with high-frequency sloping hearing loss and 25 individuals with flat frequency hearing loss.

Results: A Shapiro-Wilks test revealed a normal distribution. One-way ANOVA revealed no significant difference between the scores obtained from the two high-frequency word lists. There was a significant difference in mean speech identification scores (SIS) for individuals with high-frequency sloping hearing loss in which use of conventional word lists gave a mean score of $77 \%$ while use of the high-frequency word lists gave a mean score of $53 \%$.

Conclusions: Two high-frequency word lists each of 25 words were developed. The word lists were found to be reliable, equally difficult, interchangeable, and effective in detecting communication difficulties due to high-frequency sloping hearing loss.
\end{abstract}

Key words: audiometry $\bullet$ speech intelligibility

\section{DESARROLLO Y ESTANDARIZACIÓN DE LA PRUEBA DE IDENTIFICACIÓN DE PALABRAS DE ALTA FRECUENCIA PARA ADULTOS EN IDIOMA GUJARATI}

\section{Resumen}

Introducción: La evaluación de la audición de una persona requiere una batería de pruebas, y la información recogida se complementa, gracias a lo cual es posible determinar el grado, tipo y la configuración de la pérdida auditiva. Entre los estímulos acústicos utilizados en tales pruebas, las señales de voz son las más complejas y tienen una considerable redundancia. Por lo tanto, el uso de unas listas convencionales de palabras en la evaluación audiológica rutinaria puede, por un exceso de información, conducir a una evaluación errónea de los resultados en las personas con pérdida auditiva de alta frecuencia descendente. El gujarati es la lengua materna de 56 millones de personas en la India. Hasta ahora sólo se disponía de una prueba convencional de identificación del habla en este idioma. El presente estudio tuvo por objeto elaborar y estandarizar listas de palabras de alta frecuencia en gujarati.

Material y métodos: La prueba se realizó en tres etapas. Fase I: elaboración de listas de palabras de alta frecuencia en gujarati. Fase II: determinación de las normas para las listas de palabras desarrolladas en un grupo de 180 personas con audición normal procedentes de diferentes zonas geográficas de Gujarat. Fase III: comprobación de la aplicación en un grupo de 25 personas con pérdida auditiva de alta frecuencia descendente y en un grupo de 25 personas con pérdida auditiva plana.

Resultados: La prueba de Shapiro-Wilks mostró una distribución normal. El ANOVA de un solo factor no mostró ninguna diferencia significativa entre los resultados obtenidos de dos listas de palabras de alta frecuencia. Hubo una diferencia significativa en los resultados medios de identificación del habla en las personas con pérdida auditiva de alta frecuencia descendente: el uso de listas de palabras convencionales dio un resultado medio del 77\%, mientras que el uso de listas de palabras de alta frecuencia dio un resultado medio del 53\%.

Conclusiones: Se elaboraron dos listas de 25 palabras de alta frecuencia. Las listas de palabras demostraron ser fiables, igualmente difíciles, intercambiables y eficaces para detectar las dificultades de comunicación debidas a la disminución de la pérdida auditiva de alta frecuencia descendente.

Palabras clave: audiometría • comprensión del habla 


\title{
РАЗРАБОТКА И СТАНДАРТИЗАЦИЯ ТЕСТА ПО ИДЕНТИФИКАЦИИ ВЫСОКОЧАСТОТНЫХ СЛОВ ДЛЯ ВЗРОСЛЫХ НА ГУДЖАРАТСКОМ ЯЗЫКЕ
}

\begin{abstract}
Аннотация
Введение: Для оценки слуха используется определенный набор тестов, а полученная информация из результатов тестов дополняет друг друга при определении степени, типа и конфигурации потери слуха. Среди акустических стимулов, используемых в таких тестах, речевые сигналы являются наиболее сложными и обладают значительной избыточностью. Поэтому использование обычных списков слов во время стандартной аудиологической оценки может, из-за избыточной информации, привести к неправильной оценке результатов тестов у людей с высокочастотной потерей слуха. Гуджаратский язык является родным для 56 миллионов человек в Индии. В настоящее время в данном языке проводится только обычный тест по распознаванию речи. Настоящее исследование направлено на разработку и стандартизацию списков высокочастотных слов в гуджарати.

Материалы и методы: Исследование проводилось в три этапа. Этап I: разработка списков высокочастотных слов в гуджарати. Этап II: установление норм для составленных списков слов на группе из 180 человек с нормальным слухом, принадлежащих к различным географическим регионам Гуджарата. Этап III: проверка применимости в группе 25 человек с высокочастотной наклонной потерей слуха и 25 человек с плоским нарушением слуха.

Результаты: Тест Шапиро - Уилка выявил нормальное распределение. Дисперсионный анализ ANOVA не выявил существенных различий между результатами, полученными из двух списков высокочастотных слов. Существовала значительная разница в средних показателях идентификации речи (SIS) для лиц с высокочастотной наклонной потерей слуха, при которой использование обычных списков слов давало средний результат 77\%, в то время как использование списков высокочастотных слов давало средний результат $53 \%$.
\end{abstract}

Выводы: Составлено два спискавысокочастотных слов, каждый из которых состоял из 25 слов. Установлено, что списки слов являются надежными, одинаково сложными, взаимозаменяемыми и эффективными при выявлении трудностей в коммуникации с высокочастотной наклонной потерей слуха.

Ключевые слова: аудиометрия • разборчивость речи

\section{OPRACOWANIE I STANDARYZACJA TESTU IDENTYFIKACJI SŁÓW O WYSOKIEJ CZĘSTOTLIWOŚCI DLA DOROSŁYCH W JĘZYKU GUDŻARATI}

\section{Streszczenie}

Wprowadzenie: Ocena słuchu danej osoby wymaga przeprowadzenia baterii testów, a zebrane informacje uzupełniają się, dzięki czemu można określić stopień, rodzaj i konfigurację niedosłuchu. Wśród bodźców akustycznych stosowanych w takich testach, sygnały mowy są najbardziej złożone i mają znaczną redundancję. Dlatego stosowanie konwencjonalnych list słów podczas rutynowej oceny audiologicznej może, poprzez nadmiar informacji, prowadzić do błędnej oceny wyników u osób z opadającym niedosłuchem wysokoczęstotliwościowym. Język gudżarati jest językiem ojczystym dla 56 milionów osób w Indiach. Dotąd dostępny był tylko konwencjonalny test identyfikacji mowy w tym języku. Niniejsze badanie miało na celu opracowanie i standaryzację list słów o wysokiej częstotliwości w gudżarati.

Materiał i metody: Badanie przeprowadzono w trzech etapach. Faza I: opracowanie list słów o wysokiej częstotliwości w gudżarati. Faza II: określenie norm dla opracowanych list słów na grupie 180 normalnie słyszących osób pochodzących z różnych obszarów geograficznych Gudżarat. Faza III: sprawdzenie zastosowania na grupie 25 osób z niedosłuchem wysokoczęstotliwościowym opadającym oraz na grupie 25 osób z płaskim ubytku słuchu.

Wyniki: Test Shapiro-Wilksa wykazał rozkład normalny. Jednoczynnikowa ANOVA nie wykazała znaczącej różnicy między wynikami uzyskanymi z dwóch list słów o wysokiej częstotliwości. Istniała znacząca różnica w średnich wynikach identyfikacji mowy u osób z niedosłuchem wysokoczęstotliwościowym opadającym - użycie konwencjonalnych list słów dało średni wynik 77\%, podczas gdy użycie list słów o wysokiej częstotliwości dało średni wynik $53 \%$.

Wnioski: Opracowano dwie listy składające się z 25 słów o wysokiej częstotliwości. Listy słów okazały się wiarygodne, równie trudne, wymienne i skuteczne w wykrywaniu trudności w komunikacji z powodu niedosłuchu wysokoczęstotliwościowego opadającego.

Słowa kluczowe: audiometria • rozumienie mowy

\section{Abbreviations}

ANSI - American National Standards Institute

CVC - consonant-vowel-consonant

CVCV - consonant-vowel-consonant-vowel

CWL1 - conventional word list 1

CWL2 - conventional word list 2

FFHL - flat frequency hearing loss

HF-WITAG - high frequency word identification test for adults in Gujarati

HFSHL - high-frequency sloping hearing loss

HFWL1 - high-frequency word list 1
HFWL2 - high-frequency word list 2

SIS - speech identification score

SL - sensation level

SRT - speech recognition threshold

\section{Background}

Aural rehabilitation involves services and procedures which help individuals with hearing impairment to develop receptive and expressive communication skills [1]. The first step in the process is a thorough evaluation of the audiological dimensions of the hearing loss. These evaluations 
complement each other in defining the degree, type, and configuration of hearing loss. The two most common acoustic stimuli used clinically to assess hearing sensitivity are pure tones and speech signals. Each provides valuable information regarding the integrity of the auditory system and functional aspects of communication loss [2]. Even though pure-tone audiometry is the gold standard, it still cannot assess an individual's real-life auditory ability [3].

Speech sounds are complex and have dynamic acoustic components [4]. Usually, speech assessment tools use phonetically balanced word lists which are standardised to a flat frequency hearing loss (FFHL) configuration but not for sensorineural high-frequency sloping hearing loss (HFSHL) [5-9]. This could overestimate the performance of individuals with HFSHL and cover up the difficulties they faced in discrimination and comprehension of speech in noise [5, 10-18]. Furthermore, an individual's speech identification is influenced by their mother tongue, and so relatively higher scores are achieved if the test is carried out in the mother tongue [19-20]. High-frequency speech identification tests have been developed for understanding perceptual difficulties in individuals with HFSHL in various languages [5, 21-28]

India has a multi-lingual and multi-cultural background. The majority of the population still relies on regional languages for communication, and the number who can read and comprehend English is less. Various language-based speech assessment tools have therefore been developed [21-28]. However, the Gujarati language, one of the 23 scheduled languages recognised by the Constitution of India and the seventh-most spoken language in India, has only a Speech Identification Test as a speech assessment tool [29]. As a result, the assessment of Gujarati-speaking individuals with HFSHL is less than optimal, and available word lists are likely to be less sensitive in identifying the true nature of communication difficulties. To assess the speech identification scores in individuals with HFSHL, and so intervene with appropriate management options, it is necessary to use a test which is sensitive to the problem. Hence, the present study aimed to:

- Develop high-frequency word lists in the Gujarati language for assessing individuals with HFSHL;

- Establish norms for the developed speech identification test on people belonging to different regions of the state of Gujarat.

- Check the applicability of the word lists on a group of Gujarati speaking individuals with HFSHL.

\section{Materials and methods}

The present study followed the same methodology as used in a previous study [5]. All participants were informed about the study and written consent obtained. Ethical clearance was achieved as per the guidelines of the ethics committee of the institution. To fulfill the aim of the study, the three phases were as follows.

\section{Phase I: Development of speech identification test}

Some 300 monosyllabic (CVC structure) and 250 disyllabic (CVCV structure) words with optimum redundancy composed of voiceless consonants $\left(/ \mathrm{k} /, / \mathrm{k}^{\mathrm{h}} /, / \mathrm{t} /, / \mathrm{t} \int^{\mathrm{h}} /\right.$, $\left./ \mathrm{t} /, / \mathrm{t}^{\mathrm{h}} /, / \mathrm{t} /, / \mathrm{t}^{\mathrm{h}} /, / \mathrm{p} /, / \mathrm{f} /, / \mathrm{s} /, / \mathrm{J} /, / \mathrm{s} /, / \mathrm{h} /\right)$ in Gujarati were collected from different sources such as periodicals, newspapers, magazines, journals, general books, phonetic books, and spontaneous speech. Unambiguous and concrete words were selected which had more than $60 \%$ high-frequency phoneme content above $1 \mathrm{kHz}[30]$. The Gujarati language has different dialects across the six geographical regions of Gujarat $[31,32]$ and so in the present study the selected words were tested on 180 native Gujarati speakers from all six regions. The six regional subsets, with 30 speakers each, were Saurashtra (Subset 1), Kutch (Subset 2), North Gujarat (Subset 3), South Gujarat (Subset 4), Central Gujarat (Subset 5), and East Gujarat (Subset 6). The words were assessed on a 5-point familiarity rating scale on the 180 native Gujarati speakers (age range 18 to 35 years, mean 21.5 years, $S D 2.75$ ). They were literate with a minimum qualification of $10^{\text {th }}$ grade. The words which were rated familiar, more familiar, or most familiar by $90 \%$ of speakers in each group were included in the study.

Content validity of the words was obtained by familiarity assessment by six native Gujarati speakers qualified with Masters of Arts in Gujarati literature. The words accepted by all the experts resulted in a list of 131 words. The aim of the present study was to develop high-frequency word lists with just 25 words each. To achieve this target, a word list was constructed by randomly selecting 15 monosyllabic words in CVC structure and 10 disyllabic words in CVCV structure from the existing pool of words agreed upon by the experts. The word list consisted of $90 \%$ of voiceless

Table 1. High-frequency word lists (HFWL1 and HFWL2) developed in the Gujarati language

\begin{tabular}{|c|c|c|c|c|c|}
\hline \multicolumn{3}{|c|}{ HFWL - 1} & \multicolumn{3}{|c|}{ HFWL - 2} \\
\hline SN & Word & Transcription & SN & Word & Transcription \\
\hline 1 & સાપ & $/$ sap/ & 1 & સાજ & /saf/ \\
\hline 2 & કાચ & $/$ katg/ & 2 & પેટ & /pet/ \\
\hline 3 & છા૫ & $/ \operatorname{tf}^{2} a p /$ & 3 & हीร & $/ \mathbf{t}^{\mathbf{b}} \mathbf{i k} /$ \\
\hline 4 & તાપ & /tap/ & 4 & ફાથ & $/ h a t^{\mathrm{h} /} /$ \\
\hline 5 & કાટ & /kat/ & 5 & ફેઠે & /6het $t^{\mathrm{t} e} /$ \\
\hline 6 & ચાટ & $/$ tfat/ & 6 & સાત & /sat/ $/$ \\
\hline 7 & शेठ & $/ \mathrm{et}^{\mathrm{t} /} /$ & 7 & ધાશ & $/ \mathrm{tg}^{2} \mathrm{a} / \mathrm{f} /$ \\
\hline 8 & હેઠ & $/ \mathbf{G o t}^{\mathrm{b} /}$ & 8 & સટટ & $/ s \mathbf{U}_{\mathrm{t}} /$ \\
\hline 9 & પછ & $/$ putf $/ 2$ & 9 & ચોક & $/ \mathbf{f f o k} /$ \\
\hline 10 & dq & /veş/ & 10 & હાડ & /had/ \\
\hline 11 & જ્રલ & $/ \mathrm{ful} /$ & 11 & શણ & /fən/ \\
\hline 12 & જોશ & $/ \mathrm{d}_{3} \mathrm{O} / \mathrm{s}$ & 12 & સીપ & $/$ sip/ \\
\hline 13 & ચૃ & $/$ tfuk/ & 13 & जાટ & $/ \mathrm{k}^{\mathrm{b}} \mathrm{at} /$ \\
\hline 14 & હોશ & /6of/ & 14 & ચોર & $/$ tfor/ \\
\hline 15 & ખાસ & $/ \mathbf{k}^{\mathrm{b}} \mathbf{a s} /$ & 15 & शાร & $/ \mathrm{aak} /$ \\
\hline 16 & રથી & $/ \mathbf{f a t}^{\mathrm{b}} \mathrm{i} /$ & 16 & ટોપી & /topi/ \\
\hline 17 & ખુશી & $/ \mathbf{k}^{\mathbf{b}} \mathbf{U} \mathbf{j} /$ & 17 & કथा & $/ \mathbf{k a t}^{\mathrm{t}} \mathbf{\alpha} /$ \\
\hline 18 & ચાક & $/$ tfakU/ & 18 & પાસે & /pase/ \\
\hline 19 & સહી & /safii/ & 19 & પશ & $/ \mathbf{p}$ a $\mathbf{U} /$ \\
\hline 20 & કાથો & $/ \mathbf{k a t}^{\mathrm{b}} \mathrm{o} /$ & 20 & ચીકી & $/ \mathbf{f} \mathbf{i k i} /$ \\
\hline 21 & शाળા & $/ \int a \mid \alpha /$ & 21 & છાતી & $/ \operatorname{tg}^{2} a t i /$ \\
\hline 22 & સીડી & /sidi/ & 22 & ફાર & /har/ \\
\hline 23 & સીટી & $/$ siti/ & 23 & ભાષા & $/ b^{\mathbf{b}} a s ̧ a /$ \\
\hline 24 & पતિ & /patíI & 24 & પૈસા & /pejsa/ \\
\hline 25 & પેટી & /peti/ & 25 & शાખा & $/ \int \mathbf{a k}^{\mathrm{b}} \mathbf{a} /$ \\
\hline
\end{tabular}


consonants and $10 \%$ voiced consonants. The overall frequency of occurrence of each voiceless consonant was calculated from the word list and accordingly other word lists were created. Therefore, with inclusion and exclusion criteria as mentioned, two high-frequency word lists (HFWL1 and HFWL2) were prepared. These lists were subjected to long-term average speech spectrum analysis to ensure that the peak spectral energy of each word was above $1000 \mathrm{~Hz}$. Praat software was utilized and the words had similar spectrograms to the previous study [5], with appreciable high frequency energy. In this way, a high-frequency word identification test in Gujarati language was developed which could assess individuals with HFSHL (Table 1).

\section{Phase II: Establishment of normative data}

The participants underwent audiometric assessments including otoscopic examination, pure-tone audiometry, and immittance audiometry to ensure normal hearing sensitivity. None of them had a history of otological or neurological disorders.

The developed high frequency word-lists were tested on all 180 participants using the two high-frequency word lists. In the speech identification score (SIS) test, the stimulus was presented using monitored live voice by the experimenter at a comfortable level of $40 \mathrm{dBSL}$. Although recorded voice testing increases stability, live voice testing was performed in the present study due to the subjective preference of the participants to live speech over recordings [30]. The experimenter presented the word lists maintaining 6 inches from the microphone to avoid proximity effects due to plosives and breathing noise. Initially, 10 practice items were presented to familiarize the subjects with the test procedure. Each correct response was given a score of 1 and an incorrect response a score of 0 . The raw score was then converted into a percentage SIS score.

$$
\text { SIS }=\frac{\text { Obtained number of responses }}{\text { Total number of responses }} \times 100
$$

The SISs were calculated for each participant in each word list separately. The mean SISs obtained from the participants of each group for the two word lists were calculated.

\section{Phase III: Checking the applicability on the clin- ical population}

The developed high frequency word lists was tested on a total of 50 native Gujarati speakers ( 30 males and 20 females) aged 18 to 35 years (mean 23.5 years, SD 3.55) with sensorineural hearing loss. All participants were literate with a minimum qualification of 10th grade. None had a history of otological disorder and had normal middle ear function on immittance audiometry. The participants were further divided into two equal groups. Group I consisted of 25 participants with bilateral symmetrical moderate and moderately severe FFHL. Group II comprised 25 participants with bilateral symmetrical moderate to severe HFSHL. The SIS testing was carried out at the most comfortable level on each participant with two conventional word lists (CWL1 and CWL2) [29] and the two high-frequency word lists (HFWL1 and HFWL2) developed in the present study. The mean SISs obtained by participants of each group for the four word lists (two CWLs and two HFWLs) were calculated.

\section{Results}

\section{Analysis of the equivalency of word lists}

The mean and standard deviation of high-frequency SISs (i.e. HFWL1 and HFWL2) obtained across six different regional subsets of native Gujarati speakers were calculated as shown in Table 2.

Table 2. Means and standard deviations of SIS scores obtained across the six groups for the two high-frequency word lists (HFWL1 and HFWL2)

\begin{tabular}{lcccc}
\hline & \multicolumn{2}{c}{ HFWL1 } & \multicolumn{2}{c}{ HFWL2 } \\
\cline { 2 - 5 } Subset & $\begin{array}{c}\text { Mean SIS } \\
\text { (\%) }\end{array}$ & $\begin{array}{c}\text { Standard } \\
\text { deviation }\end{array}$ & $\begin{array}{c}\text { Mean SIS } \\
\text { (\%) }\end{array}$ & $\begin{array}{c}\text { Standard } \\
\text { deviation }\end{array}$ \\
\hline Subset 1 & 98.80 & 0.39 & 98.80 & 0.39 \\
\hline Subset 2 & 98.13 & 0.49 & 98.66 & 0.39 \\
\hline Subset 3 & 98.26 & 0.53 & 98.13 & 0.53 \\
\hline Subset 4 & 98.53 & 0.48 & 98.80 & 0.39 \\
\hline Subset 5 & 98.26 & 0.53 & 98.26 & 053 \\
\hline Subset 6 & 98.66 & 0.48 & 98.93 & 0.42 \\
\hline
\end{tabular}

A normality check was done with a Shapiro-Wilks test and the data was found to have a normal distribution $(p>0.05)$. Further, as there were six fixed subsets with two conditions (i.e. HFWL1 and HFWL2), a parametric one-way ANOVA was done to compare the mean SISs obtained across the subsets. The result indicated no significant difference $(p>0.05)$ in mean SISs across the six subsets for HFWL1 and HFWL2. The data were then further subjected to an independent sample $t$-test to check if there was a difference in the mean SISs between the two word lists among each group. The results revealed no significant difference $(p>0.05)$ in mean SISs between the two word lists among each group. Hence, both word lists in the study were equally difficult for all six subsets and could be used interchangeably.

\section{Analysis of applicability of word lists}

Two CWLs (CWL1 and CWL2) and two HFWLs (HFWL1 and HFWL2) were used to obtain SISs on the two clinical groups (i.e. FFHL and HFSHL) as summarised in Figure 1.

A Shapiro-Wilks test was performed and it was found to show a normal distribution $(p>0.05)$. The data were subjected to parametric one-way ANOVA to compare the mean SISs from the four word lists for each FFHL group. The results revealed no significant difference $(p>0.05)$ among the four word lists in the FFHL groups. Hence, it can be concluded that CWLs and HFWLs were equivalently sensitive in assessing communication difficulties due to FFHL.

A parametric one way ANOVA was done to compare the mean SISs between the four word lists for the HFSHL 


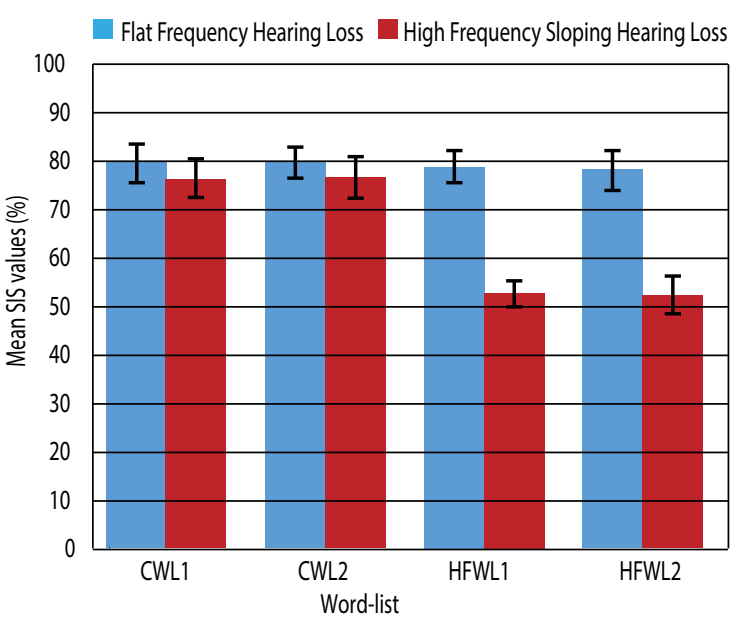

Abbreviations: CWL1, conventional word list 1; CWL2, conventional word list 2; HFWL1, high-frequency word list 1; HFWL1, high-frequency word list 2

Figure 1. Mean speech identification scores (SISs) obtained in FFHL and HFSHL groups for different word lists (CWL1, CWL2, HFWL1, and HFWL2).

group. A statistically significant difference was found $(p<0.05)$ between the CWLs and HFWLs for this group. To understand the specific information on which mean SISs among four word lists were significantly different from each other, a Least Significant Difference (LSD) post hoc analysis test was carried out. The results revealed no significant difference $(p>0.05)$ in the HFSHL group's mean SISs between the CWL1 and CWL2 word lists. Similarly, there was no significant difference $(p>0.05)$ in the HFSHL group's mean SISs between HFWL1 and HFWL2. However, the results further revealed that there was a statistically significant difference $(p<0.05)$ in the HFSHL group's mean SISs between CWLs and HFWLs (i.e. between CWL1 and HFWL1, CWL1 and HFWL2, CWL2 and HFWL1, and CWL2 and HFWL2).

\section{Discussion}

Speech identification tests have been widely used in diagnostic audiology for identification and differential diagnosis of auditory disorders [2]. A conventional speech identification test can only precisely evaluate hearing sensitivity at mid frequencies. However, HFSHL may not be well identified, meaning it has lower sensitivity to the communication difficulties faced by such individuals. Therefore, it is essential to use speech test material that contains only high-frequency speech sounds [25].

While the physiological functioning of an individual's auditory system is undoubtedly a major determinant of their hearing status, linguistic and cultural differences should not be disregarded as they can affect every stage of an audiological assessment [2]. HFWLs have been developed in various Indian sub-continental languages [5, 21-28]. However, for the Gujarati language, only one standardised and validated conventional speech assessment tool has been developed [29], a tool which is less sensitive in identifying the nature of communication difficulties caused by HFSHL. The present study was an effort to develop HFWLs in Gujarati for assessing individuals with HFSHL.

In the present study, an equivalence analysis of the two word lists was carried out to ensure both word lists were equally difficult. It was found that there was no significant difference $(p>0.05)$ in speech identification performance between the two high-frequency word lists for each group and no significant difference $(p>0.05)$ between the six subsets for each high-frequency word list. Hence, the two HFWLs were found to have equal difficulty and reliability in assessing speech identification performance. The criterion validity was carried out to determine the validity of the word list. For all normal hearing subjects, regardless of geographical subset, SIS scores for HFWL1 and HFWL2 fell above $95 \%$, which is in line with earlier studies $[5,22,23]$.

The subjects in the FFHL group obtained similar SISs for CWLs and HFWLs, suggesting that the HFWLs are found to be equally difficult and can be considered as alternatives to CWLs for assessing speech identification performance in individuals with FFHL. However, the subjects in the HFSHL group obtained significantly higher SISs for CWLs as compared to HFWLs. Hence it can be concluded that the CWLs overestimate the performance of individuals with HFSHL and do not indicate the true nature of communication difficulties caused by HFSHL $[5,14]$. The CWLs were constructed with $66 \%$ voiced consonants and $34 \%$ voiceless consonants [29] and so they might have provided redundant information [5]. On the other hand, the subjects in the HFSHL group obtained significantly lower SISs for HFWLs as compared to CWLs. This might be due to the higher difficulties individuals with HFSHL have in perceiving voiceless consonants $[5,7,8]$. Thus it can be concluded that the two HFWLs developed in the present study can be considered reliable and valid speech assessment tools in administering speech identification performance in individuals with HFSHL.

\section{Conclusion}

The present study developed a speech identification test in the Gujarati language for assessment of individuals with HFSHL. A total of two high-frequency word lists (HFWLs), each consisting of 25 words was developed. The word lists were found to be reliable, equally difficult, and interchangeable. It was confirmed that HFWLs are more effective in detecting communication difficulties caused by HFSHL compared to CWLs. Hence, these HFWLs can be used to assess perceptual difficulties in individuals with HFSHL, to gauge the benefits of hearing aids, and for research.

\section{References}

1. ASHA. Definition of and Competencies for Aural Rehabilitation. ASHA Desk Reference 1984;4:37-41

2. Gelfand SA. Essentials of Audiology, $2^{\text {nd }}$ Ed, New York: Thieme Medical Publishers, 2007.
3. Marshall L, Bacon SP. Prediction of Speech Discrimination Scores from Audiometric Data. Ear Hear, 1981; 2:148-55.

4. Niemeyer W. Speech audiometry and fitting of hearing aids in noise. Audiol 1967; 15: 421-27. 
5. Ghimire A, Prabhu P, Bhattarai B, Neupane AK. Development and standardization of high frequency word lists in Nepali. J Hear Sci, 2019; 9(3): 9-15.

6. Waghmare P, Mohite J, Gore G. Development of Marathi Speech Recognition Test (Pediatric): A Preliminary Report. J Indian Speech Hear Assoc, 2011; 25(1): 59-64.

7. Lundborg T, Riseberg A, Holmqvist C, Lindstrom B, Svard I. Rehabilitative Procedure in Sensorineural Hearing Loss. Studies on the Routine Used. Scand Audiol, 1982;11: 161-70.

8. Dean MR, McDermott HJ. Speech perception with steeply sloping hearing loss: effects of frequency transposition. Br J Audiol, 2000; 34: 353-61.

9. Cooper FS, Delattre PC, Libermann AM, Borst JM, Gerstmann LJ. Some experiments on the perception of synthetic speech sounds. J Acoust Soc Am, 1952; 24: 597-606.

10. Studebaker GA, Sherbecoe RL. Intensity importance functions for band-limited monosyllabic words. J Acoust Soc Am, 2002; 111: 1422-36.

11. Kryter KD, Williams C, Green DM. Auditory acuity and perception of speech. J Acoust Soc Am, 1962; 34: 1217-23.

12. Mullins CJ, Bangs JL. Relationships between speech discrimination and other audiometric data. Acta Oto-laryngol, 1957; 47(2), 149-57.

13. Sher AE, Owens E. Consonant confusions associated with hearing loss above $2000 \mathrm{~Hz}$. J Speech Hear Res, 1974; 17(4): 669-81.

14. Sinthiya K, Sandeep M. High frequency speech identification test in Tamil. In: Basavaraj V, Malar G (eds), "Students Research at AIISH, Mysore": Articles based on dissertations done at AIISH: Vol. VII, Part-A, Audiology, Mysore: AIISH; 2009.

15. Gardner HJ. Application of high frequency consonant discrimination wordlist in hearing aid evaluation. J Speech Hear Dis, 1971; 36(3): 354-55.

16. Pascoe DP. Frequency response of hearing aids and their effects on the speech perception of hearing impaired subjects. Ann Otol Rhinol Laryngol, 1975; 84 (supp.23): 1-40.

17. Owens E, Schurbert ED. Development of California consonant test. J Speech Hear Res, 1977; 20: 463-74.
18. Korhonen P, Kuk F, Keenan D, Peeters H, Hau O, Andersen H. Critical factors in ensuring efficacy of frequency transposition. I: Individualizing the start frequency. Hear Rev, 2001; 14: 60-67.

19. De NS. Hindi PB list for speech audiometry and discrimination test. J Otolaryngol, 1973; 25: 64-75.

20. Singh S, Black JW. Study on 26 intervocalic consonants as spoken and recognised by four language groups. J Acoust Soc Am, 1966; 39: 372-87.

21. Ramachandra. High frequency speech identification test in Hindi. Unpublished Master's Dissertation. University of Bangalore, India; 2001.

22. Kavitha EM. High Frequency Kannada Speech Identification Test (HF-KST). University of Mysore; 2002.

23. Sudipta KB. High Frequency-English Speech Identification Test (HF-ESIT). University of Mysore; 2006.

24. Sinthiya KM. High Frequency Speech Identification Test in Tamil. University of Mysore; 2009.

25. Hmangte. High Frequency Speech Identification Test in Manipuri. University of Mysore; 2012.

26. Ratnakar YV. High Frequency Speech Identification Test in Telugu. University of Mysore; 2010.

27. Reshma J. Development of High frequency Word List in Malayalam. Maharashtra University of Health Sciences, Nashik; 2001.

28. Nakhawa SC. Development and evaluation of High Frequency Word Identification Test for children in Indian-English (HF-WITCIE). University of Mysore; 2017.

29. Mallikarjuna. Phonetically balanced words in Gujarati. In: Kacker, SK and Basavaraj V. Indian Speech, Language and Hearing Test: The ISHA Battery, Mysore; 1990.

30. Carhart R. Monitored live-voice as a test of auditory acuity. J Acoust Soc Am, 1946; 17(4), 339-49.

31. Gujarati language at Ethnologue (19 ${ }^{\text {th }}$ ed, 2016).

32. Brown K, Ogilvie S. Concise Encyclopedia of Languages of the World. Elsevier; 2010. 